
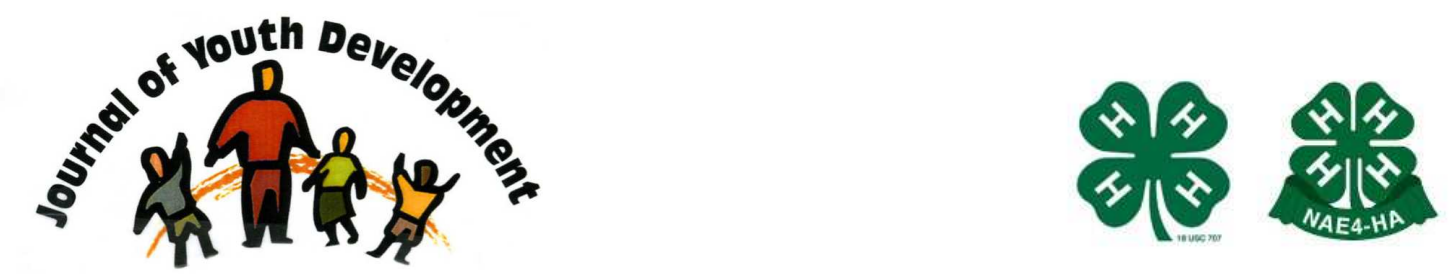

Bridging Research \& Practice

\title{
4-H Donated Meat Program: A Model for Service
}

\author{
Justen 0. Smith \\ Utah State University \\ Farmington, UT \\ justen.smith@usu.edu
}

John L. Wesley

Utah State University

Salt Lake City, UT

John.wesley@usu.edu 


\title{
JOURNAL OF YOUTH DEVELOPMENT \\ bridging research and practice

\section{4-H Donated Meat Program: A Model for Service}

\author{
Justen O. Smith and John L. Wesley \\ Utah State University
}

\begin{abstract}
Meat continues to be the most in-demand food item for the Utah Food Bank. To address this issue, the 4-H Donated Meat Program was started by a 4-H Club in Davis County, Utah. When Utah State University Extension Agents in Davis, Salt Lake, Weber, and Morgan Counties became involved in the program it expanded rapidly. The program was made possible through generous donations from corporations allowing for the purchase of market livestock exhibited by 4-H youth at county fair livestock sales. USDA certified processed meat was then donated to the Utah Food Bank for distribution to hungry families in the counties participating in the program. The program has grown rapidly. In 2005, two counties were involved with 3,000 pounds of meat donated to the food bank. By 2007, ten counties were involved with 70,000 pounds of meat donated. This program has become a model of service for hundreds of $4-\mathrm{H}$ youth in Utah. This program may be duplicated in other states to meet the demand for meat at food banks across the nation.
\end{abstract}

\section{Introduction}

The United States continues to be one of the wealthiest and most prosperous countries in the world. Although America continues to prosper, there are people in this country that go hungry every day. In 2006, statistics for the United States reported 35.5 million people lived in households considered food insecure and 12.6 million of the 35.5 million were children (Food Research and Action Center, 2007).

The statistics on hunger in Utah are sobering. One out of ten people live in poverty. A family of four living in poverty makes just over $\$ 20,600$ a year to cover health care expenses, shelter, food and other household expenses (DeNavas, Proctor, \& Smith, 2007). Utah is ranked 5th in the nation for the highest rate of food insecurity. More than 345,700 individuals are at risk of missing or skipping a meal due to a lack of resources (Nord, Andrews, \& Carlson, 2007). 
Household food insecurity is a serious concern with many implications for nutrition and health. Food insecurity has been associated with inadequate intake of several important nutrients, cognitive developmental deficits, behavioral and psychosocial dysfunction in children and adults, and poor health in children and adults (Cook, et al., 2006). Inability to purchase enough nutritious food and the resultant emotional or psychological stresses can contribute to adverse health effects or exacerbate poor health caused by other factors (Cook, et al., 2006).

Service is a major component of the 4-H program. In fact, part of the 4-H pledge identifies service, "I pledge... my hands to larger service, for my club, my community, my country and my world." 4-H experiences become transformational when youth are provided opportunities to belong, master skills, lead, and learn the meaning of service (Kress, 2003). 4-H youth enrolled in the 4-H Club in Davis County, Utah, wanted to find a way to incorporate the concept of service while helping to feed the hungry families of Utah. In 2005, under the leadership direction of 4-H leader, corporate donors, and Utah State University Extension, a model of service was created and implemented to make this concept become a reality.

\section{Program Objectives}

In order for this model of service to become successful, a number of objectives had to be identified. The 4-H Donated Meat Program objectives include:

1. Serve as a model of service for 4-H youth involved in Junior Livestock programs;

2. Supply much needed meat to hungry families in Utah;

3. Provide an avenue for corporations to fund both 4-H youth and the Utah Food Bank;

4. The distribution of donated meat would be based on funds collected from counties contributing;

5. All groups involved would claim ownership.

\section{Program Methodology}

During the first year of the program, the following steps were taken to implement the 4-H Donated Meat Program.

1. Corporate sponsors (businesses and individuals) were approached with the concept of supporting 4-H youth at the Junior Livestock Sale.

2. Corporate sponsors donated money to the 4-H Donated Meat Program fund. This fund was created under the umbrella of the Davis County Junior Livestock Program for management.

3. Donated funds were used to purchase livestock from 4-H youth at Junior Livestock Sales held at County Fairs. Livestock are either purchased directly from youth or funds are used to pay the "floor" or market price for those animals not purchased directly by buyers.

4. Livestock purchased at sales using Donated Meat Program funds were sent to packing houses to be processed. Beef, swine, and sheep were the livestock species used. The program requires that the packing houses must be USDA certified.

5. Utah State University Extension Agents in each participating county provided leadership for the logistics of getting the donated animals from the livestock sales to the packing houses. 
6. Processing (slaughter and cut/wrap) fees for the livestock were paid by funds from the Donated Meat Program.

7. The Utah Food Bank transported the processed meat from the packing houses to their main warehouse in Salt Lake City using refrigerated trucks. Processed meat consists of primarily steaks, chops, roasts, and ground meat. Processed meat is stored at the Utah Food Bank in large freezer rooms until September.

In September, after all the fairs have ended and all of the meat has been processed and transported to the food bank warehouse, a media event and service project takes place. 4-H youth from the participating counties, travel to the Utah Food Bank warehouse. They then complete a service project during the event by sorting thousands of pounds of the processed and packaged meat into smaller boxes that are shipped to smaller county food bank pantries throughout the state. News channels, newspapers, and other media outlets attend the event to showcase the generous contributions made by corporate donors and $4-\mathrm{H}$ youth.

\section{Program Results}

The outcomes of the 4-H Donated Meat Program have exceeded all expectations. In 2005, only two counties in Utah were involved in the program. In 2007, the program expanded to include nine counties in Utah and two counties in Wyoming. Table one lists the amount of meat donated to the food bank since 2005, along with the corresponding number of meals that were provided as a result of the donations.

\section{Table 1}

Amount of meat donated 2005-2007

\begin{tabular}{|l|c|c|}
\hline Year & Pounds of meat donated & Number of meals provided \\
\hline 2005 & 3,000 & 12,000 \\
\hline 2006 & 27,000 & 108,000 \\
\hline 2007 & 70,000 & 280,000 \\
\hline
\end{tabular}

As a result of this program a model of service was created called the "circle of service." The "circle of service" is outlined as follows:

- Businesses and organizations contribute funds;

- 4-H youth receive money from the sale of animals;

- Funds are then used for worthwhile causes;

- Meat is donated to families in need; and

- Gratitude is expressed to organizations and businesses.

The "circle of service" is now complete and can begin again each year. 
One family that benefited from the donated meat program wrote the following in a "thank you" letter:

"We enjoyed eating the lamb meat given to us. Also, as you know it is part of our tradition as Latinos to prepare many kinds of delicious plates with lamb meat. Thanks to your generous donations, we had the chance to feed our family and to remember our rich culture."

\section{Conclusion and Discussion}

The 4-H Donated Meat Program can be replicated anywhere a Junior Livestock program exists. Businesses and individuals already contribute funds to support youth at county fair livestock sales. Instead of taking the animal home or sending the animal with the market or "floor" buyer, they simply need to donate the animal back to a local Donated Meat Program. Donated Meat Programs can be set up through their Junior Livestock program. Further funding may be solicited from corporate sponsors so that the animals may be processed and packaged into retail cuts at USDA certified facilities. University Extension is included as a partner for facilitating the program in each county. State food banks are included in the process early on because of their years of experience in obtaining and distributing food donations. The program continues to grow rapidly each year in Utah and the same results are possible in other states.

\section{References}

Cook, J.T., Frank, D.A., Levenson, S.M., Neault, N.B., Heeren, T.C., Black, M.M., et al. (2006). Child Food Insecurity Increases Risks Posed by Household Food Insecurity to Young Children's Health. Journal of Nutrition. 136(4):1073-6.

DeNavas-Walt, C., Proctor, B., \& Smith, J. (2007). Income, Poverty, and Health Insurance Coverage in the United States: 2006. U.S. Census Bureau, Current Population Reports, P60-233, U.S. Government Printing Office, Washington, DC.

Food Research and Action Center. (2007). Hunger and Food Insecurity in the United States. < http://www.frac.org/html/hunger in the us/hunger index.html > Internet Release Date: January 17, 2007.

Kress, C. (2003). The Circle of Courage in Practice: The 4-H Club Study. Reclaiming Children and Youth. Vol. 12, Issue 1, p. 27.

Nord, M., Andrews, M., \& Carlson, S. (2007). Household Food Security in the United States, 2006. Economic Research Report No. (ERR-49). 66 pp. Available online: http://www.ers.usda.gov/Publications/ERR49

(C) Copyright of Journal of Youth Development Bridging Research and Practice. Content may not be copied or emailed to multiple sites or posted to a listserv without copyright holder's express written permission. However, users may print, download or email articles for individual use. 